DOI: 10.32844/2222-5374-2020-105-3.07

УДК: 343.988:343.346:343.71

Мозоль С. A.,

доцент кафедри кримінології та кримінально-виконавчого права

Національної академії внутрішніх справ, доктор юридичних наук,

старший науковий сіпвробітник

\title{
ВІКТИМОЛОГІЧНІ АСПЕКТИ НЕЗАКОННОГО ЗАВОЛОДІННЯ ТРАНСПОРТНИМИ ЗАСОБАМИ
}

Метою цієї статті $\epsilon$ дослідження віктимологічних аспектів незаконного заволодіння транспортним засобом та виявлення ефективних заходів запобігання злочинам зазначеної категорії з метою імплементації їх у правову дійсність Украӥни. Методологія. Методологічний інструментарій обрано відповідно до поставленої мети, специфіки об'єкта та предмета дослідження. $\quad$ п процесі дослідження здійснено узагальнення, обробку та аналіз отриманих результатів. Порівняльно-правовий метод застосовано під час аналізу чинного законодавства та міжнародних нормативних актів; статистичний - для опрацювання емпіричних даних і в процесі дослідження статистичного матеріалу з метою напрацювання математичного підгрунтя. Спеціальним методом дослідження, використаним в статті $\epsilon$ метод системного аналізу. Наукова новизна публікації полягає в тому, у зв'язку із зростанням кількості злочинів пов'язаних з незаконним заволодінням транспортними засобами в Україні, а також розвитком нових способів їх незаконного заволодіння, вивчення такої проблеми носить актуальний характер. Автором, розглянуто віктимологічні аспекти незаконного заволодіння транспортними засобами в Україні, зокрема: віктимну поведінку жертв злочину, віктимні ситуації, що детермінують вчинення даного злочину, віктимні якості жертв злочинів, віктимізацію сучасного українського суспільства. На підставі узагальнення віктимологічних аспектів незаконного заволодіння транспортними засобами запропоновано заходи запобігання злочинам зазначеної категорії. Висновки. Таким чином, для запобігання незаконному заволодінню транспортними засобами необхідно здійснювати аналіз оперативної обстановки, а також кримінологічно значущих ознак не лише особистості злочинця, але й потерпілого. Обираючи найбільш ефективні заходи запобігання незаконному заволодінню транспортними засобами необхідно постійно вивчати зарубіжний досвід та впроваджувати в діяльність правоохоронних органів України ті інновації, які свого часу показали позитивний результат в зарубіжних країнах.

Ключові слова: кримінальне правопорушення, незаконне заволодіння, транспортний засіб, віктимологія, потерпілий.

Актуальність теми. Серед представників злочинного світу транспортний засіб як спосіб незаконного збагачення користується особливою популярністю, враховуючи його мобільність, великий попит українського споживача та високі ціни на автомобілі певної марки. Тому не дивно, що викрадення транспортних засобів стало одним із найпоширеніших, найпопулярніших та над прибутковим видом злочинності. 
Даний вид злочину є одним із головних напрямів організованої злочинної діяльності. Як свідчить практика, організована злочинність практично миттєво пристосовується до будь-яких змін у суспільному житті. Тобто, є всі підстави вважати, що в майбутньому кримінальні тенденції викрадення транспортних засобів будуть розширюватись та удосконалюватись [1].

Мета та завдання публікації - здійснити кримінологічний аналіз віктимологічних аспектів незаконного заволодіння транспортним засобом. Основний акцент зроблено на запобіганні злочинам розглядуваної категорії та дослідженні проблемних питань, які виникають в процесі такого запобігання.

Виклад основного матеріалу. Сучасне суспільство розвивається максимально динамічно, а це значить, що автомобіль вже є для громадян не просто засобом пересування, а невід'ємною частиною їхнього життя. Автомобільний транспорт розвивається швидкими темпами і пропорційно цьому збільшується кількість автовласників, тому особисті автомобілі давно вже перейшли з розряду розкоші в предмети щоденного користування, в тому числі і для підприємницької діяльності. Ці фактори призвели до зростання злочинних посягань, а відповідно і зростання злочинності в цій сфері [14].

Під «запобіганням заволодінню транспортними засобами» слід розуміти діяльність, яку здійснюють згідно із законом уповноважені державою особи та інші суб'єкти, що діють на добровільних засадах, із недопущення скоєння такого злочину, усунення його причин i умов, переривання розпочатої злочинної діяльності на різних стадіях її здійснення, а також притягнення суб'єктів скоєння цього злочину до кримінальної відповідальності та застосування до них інших заходів кримінальноправового впливу [6].

Досліджуючи питання надання характеристики віктимологічного напряму запобігання незаконному заволодінню транспортними засобами, варто зазначити, що під віктимологічним запобіганням у кримінології слід розуміти спеціальну діяльність із виявлення, вивчення детермінаційного комплексу віктимності та віктимогенних факторів i вплив на них непримусовими методами; суб'єктами віктимологічної профілактики виступають численні органи, організації та особи, які цілеспрямовано їі здійснюють; враховуючи момент початку здійснення віктимологічного запобігання, необхідно виділяти ранню (заходи з виявлення й усунення віктимогенних факторів формування особи), безпосередню (спрямована на припинення процесу віктимізації осіб) і посткримінальну (здійснюється після того, як особа стала жертвою злочину) віктимологічну профілактику; віктимологічна профілактика незаконного заволодіння транспортними засобами проводиться як на рівні загальних економічних, організаційних, правових, виховних, медичних, спортивних заходів, так і на індивідуальному рівні, тобто персонально [2].

Серед віктимологічних детермінант незаконного заволодіння транспортним засобом слід виокремити:

1) зниження рівня правопорядку та загалом ефективності захисту законних прав, свобод та інтересів особи, суспільства й держави загалом, що спричинило підвищення рівня віктимізації в Україні (особливо вразливими у цьому контексті $€$ території на Донбасі); 
2) великий потік біженців з окупованих територій на Сході України та Криму, кількість і подальшу міграцію яких у подальшому правоохоронні органи не відслідковують, що створює для цієї категорії осіб умови для незаконного заволодіння транспортними засобами;

3) транспортні засоби, на яких переміщені із Сходу України та Криму особи прибули 3 окупованих територій, не зареєстровано в місцевих підрозділах поліції, що створює умови для вчинення даного злочину, оскільки на їх розшук необхідні додаткові інформаційні ресурси, час, сили та засоби;

4) інші віктимологічні детермінанти (зловживання правом і тимчасове заволодіння чужими транспортними засобами правоохоронними органами та іншими воєнізованими формуваннями; значне зниження життєвого рівня населення за останні роки, що зумовлює, зокрема, необхідність протиправного пересування громадян на чужому транспорті до місця роботи, навчання, проживання) [11].

5) Зазначимо, що раніше транспортні засоби викрадали переважно на замовлення чи перепродаж, проте нині злочинці не бажають ускладнювати собі життя. Саме тому, більшість автомобілів здають на запчастини, де їх без документів розбирають та продають через інтернет. Факторів, що зумовлюють таку ситуацію не мало. Кількість угонів сприяє недостатній контроль за функціонуванням ринку вживаних автомобілів, запчастин, пунктів прийому металобрухту з боку органів державної влади та місцевого самоврядування, недосконала система реєстрації та обліку автотранспорту, яка дозволяє легалізувати викрадені авто, а також відсутність регулярного технічного огляду приватного автотранспорту [16].

Результати проведеного дослідження підтвердили, що потерпілими від незаконного заволодіння транспортного засобу, як правило є фізичні особи, але інколи це можуть бути юридичні особи. Також слід зазначити й обумовлений зв'язок особи потерпілого і зацікавленістю злочинців, що вчиняють незаконне заволодіння транспортного засобу. У більшості випадків останні завчасно знають про особу потерпілого, що керує (володіє) транспортним засобом, котре викликало злочинний умисел як предмет кримінального правопорушення. У зв'язку 3 цим співучасники кримінального правопорушення як жертву обирають конкретну особу. Подібні роздуми дають змогу визначати певні типи осіб, які стають жертвами незаконного заволодіння транспортним засобом [10].

Ми цілком погоджуємося із О.М. Брисковською, яка виділяє таку типологію потерпілих: засобу;

- перший тип - надмірно самовпевнені власники транспортного

- другий тип - власники транспортного засобу з необережною або легковажною поведінкою, що сприяє учиненню кримінального правопорушенню;

- третій тип - власники, які добровільно, внаслідок обману, особисто передають транспортний засіб злочинцям [13].

Доволі суперечним є твердження окремих авторів про те, що особу потерпілого злочинці враховують лише при посяганнях, пов'язаних 3 безпосереднім контактом, а у випадку таємного заволодіння - нехтують нею. Результати проведеного нами дослідження показують, що у більшості 
випадків вчинення як відкритих, так і таємних заволодінь злочинцями здійснюється збір інформації про власника транспортного засобу [10].

Під час вивчення кримінальних проваджень нам вдалось здійснити аналіз демографічної характеристики потерпілих від незаконного заволодіння транспортними засобами. На нашу думку, логічно буде сказати, що злочинці, як правило, повинні обирати жертв учинення досліджуваних злочинів із кола осіб, більш слабких у фізичному плані, зокрема осіб жіночої статі. Проте аналіз кримінальних справ дав змогу встановити, що потерпілими від незаконного заволодіння транспортним засобом, частіше стають чоловіки - 6 \% проти 3 \% потерпілих-жінок. Вважаємо, що таку тенденцію можна пояснити тим, що сьогодні водіями транспортних засобів у переважній кількості випадків є чоловіки.

Цілком логічним також $\epsilon$ те, що частіше за все потерпілими від злочинних посягань на транспортний засіб стають громадяни України (96,1\%), тоді як у 3,9\% випадків - іноземці. За віковими категоріями потерпілих переважають особи 30 років і старше (62\%), 38\% складають особи від 18-30 років.

За рівнем освіти потерпілих категорії розподіляються наступним чином: особи, які мають вищу освіту, складають 59,5\%, середня спеціальна 20,7\%. При розгляді сімейного стану постраждалих від розкрадань їх коштів встановлено, що більшість жертв на момент вчинення злочину перебували в шлюбі.

За трудовою діяльністю найбільш уразливою категорією населення $\epsilon$ особи, які працюють в таксі, водії, які займаються перевезенням вантажів, особливо на дальні відстані.

Зважаючи на морально-психологічні особливості найбільша віктимність характерна для заможних осіб, осіб, пов'язаних з кримінальним середовищем, тих хто розпиває спиртні напої в гаражах та машинах, наркомани, особи нерозбірливі в зв'язках, інфантильні чи довірливі водії.

Таким чином, соціально-демографічна структура потерпілих від незаконного заволодіння транспортними засобами складається з людей зрілого віку, чоловічої статі, які перебувають у шлюбі, майже в кожному другому випадку мають вищу освіту, більш того, значна частина 3 них відноситься до категорії інженерно-технічних працівників або зайнята в сфері розумової праці [12].

Варто також зазначити, що у більшості випадків особистісні, а тим більше поведінкові особливості жертви грають далеко не останню роль в механізмі злочинної поведінки під час незаконного заволодіння транспортними засобами.

Дослідженням особливостей віктимологічного фактору незаконного заволодіння транспортними засобами встановлено, що потерпіла особа від незаконного заволодіння транспортним засобом має власні характерні риси, які, в свою чергу, в певній мірі обумовлюють і полегшують реалізацію злочинного прояву. Відповідний рівень віктимності даної особи має суттєве значення для реалізації механізму індивідуального злочинного прояву, спрямованого на незаконне заволодіння транспортним засобом [2].

Першим в числі віктиміногенних факторів слід назвати небажання автовласників обладнати свій транспортний засіб протиугінною охоронною сигналізацією. Наприклад, слід зауважити, що $\epsilon$ такі сигналізації, коли потрібно не тільки завести машину, а й набрати якийсь код. Як правило, код 
складається 3 декількох маніпуляцій: відкрити вікно, натиснути кнопку,закрити вікно і так далі. Дізнатися алгоритм неможливо, а для того аби відключити такий захист злодіям необхідно докласти додаткових зусиль, в той час коли поруч стоїть точно такий же автомобіль. Крім того, дуже часто ті деякі власники, які погодилися на установку такого захисту, відмовляються від нього адже втомлюються кожен раз так заводити автомобіль, приїжджають в сервіс і відключають цю функцію [4].

С.В. Краснобаєв визначив й інші віктимологічні фактори, що сприяють вчиненню злочину, пов'язаного з незаконним заволодінням транспортними засобами, а саме:

1) психічне насильство стосовно потерпілого, що пов'язане з погрозою позбавлення життя $(8,9 \%) ;$ нанесення шкоди для здоров'я $(16,2 \%) ;$ погроза знищення автомобіля або іншого майна $(19,6 \%)$;

2) фізичне насильство стосовно потерпілого від злочину, що виражалось у нанесенні шкоди його здоров'ю (12,5\%); у виштовхуванні водія на світлофорі 3 подальшим незаконним заволодінням транспортними засобами (25 \%); пошкодження майна (8,9\%);

3) обман (використання офіційних документів (для проведення певних ремонтних та інших робіт)) [9].

Підвищену віктимність мають автомобілі з безключевим доступом в салон i кнопкою запуску двигуна. Незаконне заволодіння такими автомобілями можуть здійснюватися як на парковках в громадських місцях, так і з прибудинкової території. Як правило, злодії діють в групі: один слідує із спеціальним технічним пристроєм за власником автомобіля, а інший, 3 таким же пристроєм, знаходиться біля машини і натискає кнопку відмикання замка або смикає за ручку, щоб пішов сигнал на ключ [5].

Необхідно вказати і на те, що мало хто з автовласників використовує сьогодні додаткові протиугінні пристрої - електронні (іммобілайзери, «секретки») або механічні (Замки коробки перемикання передач, капота, запалювання, рульового колеса, дверей; блокатори рульового колеса, педалей і ін.) [5].

Основна ідея додаткових засобів захисту полягає в тому, що будь-який викрадач, зіткнувшись з додатковою перепоною, швидше за все, обере автомобіль без будь-яких засобів. Однак, справедливості заради, потрібно сказати, що є група автомобілів, при зазіханнях на які наявність сигналізації, а також інших пристроїв проти викрадення (Супутникові або GSM, що забезпечують захист і оповіщають власника про будь-які дії з його автозапуск двигуна, відкриття дверей та ін.) не відлякує злодія [5].

Найбільш криміногенними сезонними періодами незаконного заволодіння транспортними засобами $\epsilon$ «сезони їх експлуатації» (квітеньжовтень) (Svirin, 2010). Це пов'язано з тим, що погодні умови можуть суттєво ускладнити якість підготовки, вчинення й приховування злочину. Поряд 3 цим власники приватних транспортних засобів влітку перебувають у відпустках і не володіють інформацією про стан збереження (охорони) транспортних засобів, що, у свою чергу, полегшує вчинення незаконного заволодіння транспортних засобів, які знаходяться на стоянках, у приватних гаражах тощо [10].

Окремо можна виокремити жертв, які, покидаючи автомобіль, залишають відкритими двері, опущеними вікна, а також не витягують ключі 
із замка запалювання. Деякі автовласники передають ключі від автомобіля стороннім або малознайомим особам [5].

Наступним фактором, який зумовлює віктимність, слід назвати залишення власниками транспортних засобів на відкритих неохоронюваних ділянках місцевості (парковках, узбіччях доріг, неохоронюваних стоянках, прибудинкових територіях, а не в гаражах або на стоянках, що охороняються). Вісім злочинів з десяти були здійснені в темний час доби вечірній і нічний, коли автовласники, приїхавши додому, залишили авто на не охоронюваних парковках, прибудинкових територіях. Власники не усвідомлюють, а іноді і халатно ставляться до загрози втрати свого транспортного засобу [5].

Так, за даними вивчених кримінальних проваджень місцем вчинення незаконних заволодінь транспортних засобів стали: 1) вулиця (проїзна частина) - 57\%; 2) станція технічного обслуговування - 8\%; 3) двори будинків - 9\%; 4) стихійні автостоянки (тимчасові стоянки біля магазинів, офісів підприємств) - 17\%; 5) приватні гаражі - 6\%; 6) гаражі кооперативів $2 \%$; 7) інше - 1\% [10].

Крім цього, у науковій літературі називаються й інші віктимологічні ситуації, що детермінували вчинення незаконного заволодіння транспортними засобами. Зокрема, Л.Р. Аветисян встановив, що в 34,2\% цей злочин вчиняли через неприязні стосунки злочинця й потерпілого. Серед інших віктимологічних факторів (ситуацій) Л.Р. Аветисян називає: а) халатне ставлення жертв цього злочину до збереження автотранспорта - 84,7 \% від загальної кількості незаконного заволодіння цими транспортними засобами; б) віктимологічну (провокуючу) поведінку жертви - 32,6\%; в) відсутність сучасної системи охорони автомобіля або іншого транспортного засобу 35\%; г) кримінальне походження транспортного засобу - 1,65\%; г) міжособистісний конфлікт злочинця та жертви - 7,15\% [8].

Також можна зазначити, що іноді злочинців спонукає до вчинення незаконного заволодіння транспортним засобом такі віктимні ситуації, зокрема, це можуть бути бажання зміцнити свій авторитет серед знайомих, випробувати власні водійські навички, доїхати до певного місця, перевезти багаж, вчинити інший або приховати вже скоєний злочин із використанням транспортного засобу, примусити його власника до вчинення певних дій, помста, заздрість, альтруїзм, хуліганські спонукання тощо. Наявність складу аналізованого злочину вбачається й, наприклад, у разі заволодіння транспортним засобом потерпілого в рахунок погашення його боргу [3].

Таким чином, можна виокремити основні віктимологічні аспекти незаконного заволодіння транспортними засобами, зокрема: нехтування власниками транспортних засобів установкою сигналізації і додаткових протиугінних засобів, системи супутникового стеження; наявність в автомобілі

безключового доступу в салон та кнопки запуску двигуна; небажання залишати транспортний засіб на охоронюваній стоянці або в гаражі; необережність і безпечність водіїв по відношенню до автомобільних ключів.

Задля уникнення ситуацій, коли транспортний засіб протизаконно переходить у володіння сторонніх осіб, слід проводити профілактичну роботу за матеріалами кримінального провадження, звертати увагу на власників транспортних засобів, які не здійснюють заходів, спрямованих на збереження їхньої власності. 
Передусім транспорт не мають залишати без нагляду, на необладнаних стоянках важливо встановлювати щодобове чергування його власників, особливо якщо на них залишають престижні марки автомобілів. Кожен власник повинен мати перелік номерів свого автомобіля, знайти зручний для нього спосіб, що перешкоджає викраденню транспортного засобу. Для цього можуть бути використані додаткові замикаючі, блокувальні чи сигнально-сторожові пристрої, спрацювання яких створює додаткові сліди під час незаконного заволодіння транспортним засобом. Щоб запобігти його викраденню, слід скористатися попереднім маркуванням окремих вузлів транспортних засобів (коліс, скла тощо). Комплексне використання профілактичних технічних засобів має вагоме значення для запобігання незаконному заволодінню транспортним засобом, a ïx поєднання 3 організаційними заходами, вживаними 3 урахуванням конкретної обстановки, найефективніше сприяє запобіганню цьому виду злочинів [15].

Автором окреслено ключові віктимологічні аспекти незаконного заволодіння транспортним засобом. У статті з'ясовано специфіку та виокремлено кримінологічно значущі ознаки потерпілого від незаконного заволодіння транспортним засобом. На основі аналізу запропоновано заходи віктимологічного запобігання злочинам розглядуваної категорії.

Висновки. Підсумовуючи, варто зазначити, що віктимологічні аспекти незаконного заволодіння транспортними засобами в Україні можна класифікувати на такі групи:

1) віктимна поведінка жертв злочину (недбале ставлення до забезпечення охорони транспортного засобу; некритична оцінка потерпілої особи до вчинюваних нею дій щодо забезпечення технічної безпеки транспортного засобу; довірливе ставлення до оточуючих їі осіб та самовільна передача транспорту останнім;);

2) віктимні ситуації, що детермінують вчинення даного злочину (заволодіння транспортним засобом з охоронюваних територій, гаражів та стоянок; заволодіння цим засобом за підробленими документами чи втраченими посвідченнями працівників правоохоронних органів;

3) віктимні якості жертв злочинів (наявність певних елементів антисуспільної настанови особи, домінуючими з яких є безвідповідальне ставлення до свого майна; неуважність; хизування своїми статками;);

4) віктимізація сучасного українського суспільства, що пов'язана 3 низьким рівнем соціально-матеріального забезпечення громадян; неефективною діяльністю правоохоронних органів, а також самочинними діями й присвоєнням функцій останніх окремими громадськими об'єднаннями та громадянами [11].

\section{СПИСОК ВИКОРИСТАНИХ ДЖЕРЕЛ}

1. Безуглий, О.А. Характеристика сучасних способів незаконного заволодіння транспортними засобами. Кримінологічна теорія і практика: досвід, проблеми сьогодення та шляхи їх вирішення. 2014. URL: http://elar.naiau.kiev.ua/jspui/handle/123456789/10769.

2. Горшков Д.В. Незаконне заволодіння транспортними засобами кримінологічна характеристика та запобігання : автореф. дис. на здобуття наук. ступеня канд. юр. наук : спец. 12.00.08. Харків, 2016. - 19 с.

3. Дуров 0.0. Незаконне заволодіння транспортним засобом: проблеми кваліфікації та вдосконалення кримінального законодавства. 
Юридичний науковий електронний журнал. № 2. 2020. DOI: https://doi.org/10.32782/2524-0374/2020-2/80.

4. Интервью с угонщиком: кто и как похищает автомобили. 2020. URL: https://ria. ru/20170621/1496946472.html.

5. Тимко С.А., Подшивалов А.П. Виктимологические аспекты краж и угонов автомобилей. Виктимология. 2019. № 2 (20). URL: https://cyberleninka.ru/article/n/viktimologicheskie-aspekty-krazh-i-ugonovavtomobiley.

6. Семенишин М. Запобігання незаконному заволодінню транспортними засобами як об'єкт кримінологічного дослідження. Підприємство, господарство і право. 2020. DOI: https://doi.org/10.32849/2663$5313 / 2020.4 .59$.

7. Свірін М. О. Запобігання органами внутрішніх справ незаконному заволодінню транспортними засобами : дис. ... канд. юрид. наук : 12.00.08. К., 2010. 227 c.

8. Аветисян Л. Р. Неправомерное завладением автомобилем или иным транспортным средством без цели хищения: уголовно-правовые и криминологические аспекты : автореф. дис. на соискание ученой степени канд. юрид. наук : спец. 12.00.08. Тамбов : Тамбов. гос. ун-т имени Г.Р. Державина, 2009. - 22 с.

9. Краснобаев С. В. Неправомерное завладение автомобилем или иным транспортным средством без цели хищения: уголовно-правовые и криминологические аспекты : автореф. дис. на соискание ученой степени канд. юрид. наук : спец. 12.00.08. Уфа : Уфим. гос. ун-т, 2009. 20 с.

10. Христов О.Л. Протидія незаконним заволодінням транспортними засобами: криміналістичний аспект: монографія. Дніпро: Дніпроп. держ. ун-т внутр. справ, 2017. 148 с.

11. Колб С.О. Запобігання незаконному заволодінню транспортними засобами в Україні : дис. канд. юр. наук : 12.00.08. Київ, 2016. 263 с.

12. Павлик Е.М. Виктимологическая характеристика жертв хищений транспортных средств. Царскосельские чтения. 2015. № XIX. URL: https://cyberleninka.ru/article/n/viktimologicheskaya-harakteristika-zhertvhischeniy-transportnyh-sredstv.

13. Брисковська O.M. Віктимологічна профілактика незаконного заволодіння автотранспортними засобами. URL: http://www.nbuv.gov.ua/old_jrn/Soc_Gum/Juptp/2011_1/brusk.htm.

14. Грицай Я.Е., Сильченко Е.В. Объект неправомерного завладения автомобилем или иным транспортным средством без цели хищения. Центр научного сотрудничества «Интерактив плюс» №6(28). 2018. DOI: $10.21661 / \mathrm{r}-471795$.

15. Моргун Н.С. Типові слідчі ситуації, що виникають під час розслідування незаконного заволодіння транспортним засобом, встановлення його місцезнаходження та причетних до цього злочину осіб / Моргун Н.С., Сєдакова В.В. Наукові записки НаУКМА. Юридичні науки. Т. 3. 2019. DOI: $10.18523 / 2617-2607.2019 .3 .88-93$.

16. Кіріленко Ф.0. профілактика та запобігання незаконному заволодінню транспортними засобами / Кіріленко Ф.О., Мінаєв Д.Д. // Південноукраӥнський правниий часопис. 2019. http://www.sulj.oduvs.od.ua/archive/2018/1/17.pdf. 


\section{S. Mozol}

\section{VICTIMOLOGICAL ASPECTS OF ILLEGAL POSSESSION OF VEHICLES}

The purpose of this article is to study the victimological aspects of illegal possession of a vehicle and identify effective measures to prevent crimes of this category in order to implement them into the legal reality of Ukraine. Methodology. Methodological tools are selected in accordance with the purpose, specifics of the object and subject of research. In the course of the research the generalization, processing and analysis of the obtained results were carried out. The comparative legal method was used in the analysis of current legislation and international regulations; statistical - for the processing of empirical data and in the process of studying statistical material in order to develop a mathematical basis. A special research method used in the article is the method of system analysis. The scientific novelty of the publication is that in connection with the growing number of crimes related to illegal possession of vehicles in Ukraine, as well as the development of new ways of illegal possession, the study of this problem is relevant. The author considers the victimological aspects of illegal seizure of vehicles in Ukraine, in particular: victim behavior of crime victims, victim situations that determine the commission of this crime, victim qualities of victims of crime, victimization of modern Ukrainian society. Based on the generalization of victimological aspects of illegal seizure of vehicles, measures to prevent crimes of this category are proposed. Conclusions. Thus, in order to prevent the illegal seizure of vehicles, it is necessary to analyze the operational situation, as well as criminologically significant features not only of the identity of the offender, but also of the victim. Choosing the most effective measures to prevent illegal seizure of vehicles, it is necessary to constantly study foreign experience and implement in the activities of law enforcement agencies of Ukraine those innovations that once showed a positive result in foreign countries.

Keywords: criminal offense, illegal seizure, vehicle, victimology, victim. 